\title{
'Use-Value' and the Re-thinking of Skills, Learning and the Labour Process
}

\author{
Peter H. Sawchuk \\ University of Toronto
}

\begin{abstract}
Reviewing multiple traditions of social analysis of work, skill and knowledge this article seeks to renew the possibility for a critical, integrated approach. Contextualizing and then criticizing the ongoing 'up-skilling/de-skilling impasse', I offer discussion of several alternative conceptual resources that may contribute to a more robust appreciation for learning and human development, potentially unified under a suggested 'Use-Value Thesis' on the labour/ learning process. It is argued that recognizing 'use-value' sets the stage for a broader systemic understanding of the contradictory processes (e.g. up-skilling/de-skilling, engagement/alienation, co-operation/conflict) that occur simultaneously in all workplaces under capitalism, and in turn offers a means to more coherently assess the full range of human learning.
\end{abstract}

Keywords: cultural historical activity theory; de-skilling debate; labour process theory; use-value thesis

\section{Introduction}

This article emerges from questions posed by a current, large-scale research project exploring work and technological changes in Canada. ${ }^{1}$ Simply put, our data analysis came to demand an approach that was not available in the existing

Contact address: Peter Sawchuk, Department of Sociology \& Equity Studies in Education, Ontario Institute for Studies in Education, University of Toronto, 252 Bloor Street West, Toronto, Ontario, Canada $\mathrm{M}_{5} \mathrm{~S}$ IV6 [email: psawchuk@oise. utoronto.ca] 
industrial relations, sociology of work and Labour Process Theory (LPT) literature. Focusing on questions of work, skill and knowledge as well as resistance and co-operation, in order to develop the potential for critical, integrated analysis of actual human developmental processes I review sociology of work and LPT literature.

Our research asked: is a simple recovery of the 'de-skilling' thesis as suggested in our research team's initial analyses, adequate to describe the processes we were seeing? Likewise, should various competing models of work change such as Daniel Bell's post-industrial thesis, Manuel Castells' network society thesis, post-Fordism, flexible specialization, lean production, high performance production, up-skilling or re-skilling theses be substituted, appended or referenced? In light of our emergent findings, a number of models were reassessed for their ability to illuminate, in particular, the contradictory nature of labour/learning processes. Our evidence forced us to consider the ideas of de-skilling, up-skilling, their mutual constitution and their simultaneity. In our project's search for answers, we viewed paid work as definitively historical and social; and quickly determined that the most powerful conceptualizations recognize not simply skill but processes of human development/learning. In this sense, the separation of analyses of work and analyses of learning was deemed a key barrier to be overcome.

As I will discuss, research in sociology of work and LPT has continued to evolve since World War II from the 'industrialism thesis', through 'post-industrialism thesis' and the challenge inspired by the work of Harry Braverman that introduced a more critical, Marxist perspective. I argue that we're now faced with a 'de-skilling/up-skilling impasse': roughly equal proportions of persuasive work/skills research demonstrating that disempowerment and resistance occur, new forms of technological and socio-emotional control occur, rising educational requirements and attainments continues to occur, de-skilling occurs, and up-skilling occurs - all with little agreement as to their inter-relations. The trend continues most recently through the detailed arguments about what does or doesn't constitute 'knowledge work', 'knowledgeability at work', traits as opposed to skills, and what exactly constitutes a 'new' knowledge economy. Emphatically, I claim that the mere proliferation of identification of different forms of work, skill, knowledge, ability, competencies, performances or practices, does not, in itself, constitute a break in this impasse, but rather pushes it to new levels of complexity. I suggest the need to conceptualize the inter-relations amongst these findings, and go on to say that in doing so we must avoid losing the critical Marxist observations that fuelled the original challenge to the industrialism/post-industrialism theses in the first place.

Central to breaking the impasse is a recognition of the pervasive contradictions that shape work under capitalism and also fuel the learning process. This is the substance of a proposed Use-value Thesis; a thesis that understands the labour and learning processes within a unified analysis drawing on a specific form of socio-cultural learning theory called Cultural Historical Activity Theory (CHAT). 
Below, I briefly review past and present sociology of work and LPT contributions, and make the case for the need to find a unifying conceptual framework of inter-relations. Toward this end, I then present several additional theoretical resources for this Use-value Thesis on the labour/learning process, concluding with a brief discussion of its implications.

\section{Research on Skill, Knowledge and Work: Contextualizing the Critique}

As a matter of establishing the basic historical context for my argument, it is important to recognize that the two decades immediately following World War II were in many ways definitive for current debates surrounding theories on the work process today. What became known in several distinct but nevertheless closely related guises as the 'industrialism thesis' (e.g. Blauner, I964; Dahrendorf, I959; Friedmann, I96r; Kerr, Dunlop, Harbison and Myers, I962; Touraine, I97I) posited the emergence of a type of society in which social progress was realized through diminishing conflict, heightened co-operation and, in particular, expansive economic growth. Soon after the related 'post-industrialism thesis' emerged which added analysis of new, technologically advanced ('labour-saving') paid work and better, wider, and presumably more skilled, participation. In a key work, Daniel Bell's The Coming of the Post-Industrial Society (1973) solidified what seems to remain today the basic contemporary formulation. Across these industrial and post-industrial theses, and all the specific variations, it is argued that routinized (and particularly physically exhausting and/or repetitive work) is year by year being replaced by new technology and work systems that require greater use of information, knowledge, greater discretion, smarter workers and symbolic analysts, all fueled by advanced education and training: like the dinosaurs, it was argued, 'bad jobs' were to simply become extinct.

It is only a slight exaggeration to say that this characterization presents us with a monolithic view of where the western world was and where it was headed. Certainly proponents would be quick to note what they see as important distinctions, in later research rooted in among other matters, a more lucid appreciation for globalization, technology and dynamic sectoral or niche market effects. Nevertheless, in response to the industrialism/post-industrialism theses, in the early I970s the work of Harry Braverman was published. With particular (though not exclusive) attention to Scientific Management as embodied in the turn of the century writings and public campaigning of Frederick $W$. Taylor, in Labor and Monopoly Capital: The Degradation of Work in the Twentieth Century (I974) Braverman sought to recover a Marxist analysis of work to develop what became known as 'Labour Process Theory'. Braverman LPT did not deny as relevant but, all the same, largely set aside subjective dimensions of work and workers to focus on the so-called objective processes and outcomes of the Taylorist divisions of labour. He re-analysed the effects of the separation of conception and execution and argued these to be an expression 
of management's war with (craft and office) workers for control and through it heightened exploitation and profitability. Specifically, Braverman tried to demonstrate that, on an aggregate level, the Taylorized technical division of labour - fragmenting jobs into minute actions and re-arranging activity based on management prerogative - was aimed at breaking down knowledge forms and the power that skilled workers exercised within the production process.

What ensued thereafter was a three decade long debate over whether work was being 'up-skilled', 're-skilled' or 'de-skilled'. As Wardell, Steiger and Meiksins noted, ' $[\mathrm{t}$ ] o casual observer it might have appeared as if, for every researcher who attempted to follow in Braverman's footsteps, another researcher attempted to challenge, if not discredit, Braverman's work...' (I999: I-2). Initially, three relatively distinct clusters of scholarship emerged. First, advancing a (post-)industrialism and up-skilling thesis were the likes of Wood (1982), Hirschhorn (1984), Attewell (1987), Spenner (1979, I983, I988, I990) and Zuboff (I988), and more recently Nonaka and Takeuchi (1995) and Frenkel, Korczynski, Shire and Tam (I999). Initially, this cluster tended to critique Braverman's pre-occupation with social class, his emphasis on (indeed many said his romanticization of) manufacturing-based craft skill, his excessive emphasis on Scientific Management, and his lack of attention to other sectors where new skills were on the rise. As Wood (1982) persuasively established early on, skill is not only a label used by management to divide and reduce the power of workers or the product of workers' collective resistance.

Alternatively, building on the Braverman LPT approach through more constructive criticism and application were writers in Zimbalist (1979), as well as Friedman (1977), Edwards (1979), Burawoy (1979, 1985) and Littler (1982); with important extensions of thinking found in Hales (I980), Pollert (I98I), Westwood (1984) and Cockburn (1985) as well as in several more recent contributions (e.g. Baldry, Bain and Taylor, I998; Beirne, Ramsay and Pantelli, I998; Milkman, I998; Ritzer, I998). This second cluster expanded upon Braverman's thesis, either implicitly or explicitly, through greater attention to the subjective dimensions of the labour process (such as worker consciousness, resistance and consent) and later sought to address Braverman's exclusion of gendered divisions, while still others pointed toward the need to deal with more than simply manufacturing sites, to develop a more detailed understanding of command/control structures as well as macro economic factors, and eventually globalization with the latest research offering explanations of the effects of advanced technology.

Setting aside a relatively brief attempt to establish a 'contingency theory' of labour process and skill analysis in the late r 980 os and early 9os (e.g. Form, Kaufman, Parcel and Wallace, I988; Kelley, I990), a third major cluster of scholarship that should be registered was an energetic sub-stream that sought to radically transform the question of subjective dimensions of LPT by convening a search for the 'missing subject'. In terms of work analysis, post-structuralism emerged in the I990s, largely in Britain, as fuel for the critique of Braverman LPT. The most prominent and persistent figure of the post-structuralist stream 
to date has been David Knights (e.g. I990, 2000-I; see also Parker, I999). It was eventually determined that what was lost in this approach, at least according to some authors (e.g. O'Doherty and Willmott, 200I; Tinker, 2002), was a coherent model of material and historical dimensions that ultimately define the period itself as capitalist. O'Doherty and Willmott provide a direct review of the Foucauldian-inspired post-structuralist 'anti-realist' stream in relation to 'realist' orthodoxy of Braverman LPT with the goal of constructive synthesis. This goal centred on efforts to maintain/re-develop a perspective on 'the complex-media of capital-labour relations, that difficult space where work organization gets produced and reproduced in the everyday accomplishments of agency and social interaction' (200I: 458-9). To do this, O'Doherty and Willmott (200I) drew persuasively on the work of Storey (1985) who in the mid-8os challenged functionalist presumptions of several LPT variants which, he argued, did not assess the multiple levels, circuits and forms of control that may not directly relate to the logic of capitalism alone; that even the control located in the workplace itself is subject to struggles both between and within worker and managerial groups; a view with which the alternative framework I propose in this article has a good deal of sympathy.

Although Smith and Thompson (1999) have argued that, in some ways it may be misleading to allow the industrialism, post-industrialism and Braverman LPT debate to degenerate simply into an up-skilling versus de-skilling impasse, in many ways it has done just that. Warhurst, Grugulis and Keep (2004: 5) maintain that ' $[\mathrm{m}]$ any of the academics involved in the up-skilling/de-skilling debates have tended to talk past each other and certainly have avoided direct debate'. Beyond the sources of confusion that Braverman himself preemptively identified (1974: Article 20), ${ }^{2}$ contributing to the quagmire was, first, the matter of the many new paradigms of work that seemed to blossom like weeds in the context of accelerating economic changes, premised on new technology and increased, globalized competitive pressures that came with the neo-conservative resurgence of the 1980 and 90 across many industrialized countries. Practically speaking, it took time for researchers to separate the fact from fiction regarding the apparently new work and technological systems. A contributing factor to the challenges of analysis were the new 'magic bullets' of managerial and organizational prescription - from synergies, to quality production, just-in-time, lean, agile and reengineered organizations, not to mention the 'learning organization'; dense, new discourses, implicitly framed by industrialism/post-industrialism ideas, seeped into popular consciousness of working life making matters even more difficult to assess. Thus, the post-industrialism thesis established in the work of Bell in many ways found continuing expression. The I980s and early I990s saw distinctive contributions that, at least on the surface, seemed to end-run the up-skilling/de-skilling debates. Piore and Sabel (1984), Streeck (1989), and Womack, Roos and Jones (1990) demonstrated cases of a re-emergence of new forms of craft labour, multi-skilled occupation or re-professionalization that apparently went hand-in-hand with the autonomy required by expensive new technologies and more sophisticated 
consumer demands. The tenor of the argument was, for example, that under conditions of flexible specialization capital is forced to transform production in ways supportive of workers' interests by virtue of the need for their intelligence, skill and participatory capacities. The critique of this research was centred on whether such cases were isolated, would last, or spread; many such analyses eventually came to be understood as what Thompson (2003) referred to as 'virtuous circle' theories, and what Braverman called 'nostalgia for age that has not yet come into being' (1974: 7).

Today, as Warhurst et al. (2004: 5) claim, some basic forms of consensus around skill and work have developed. In reviewing contributions within their edited volume and beyond, they argue that researchers mutually acknowledge several key principles:

i) skill includes internalized capacities resident in the individual worker;

ii) skill includes job design, divisions of labour, technology and control; and iii) skill is socially constructed.

Taking a look at this list in comparison to, for example, the principles attended to by Littler (1982: task elements, social construction and control), Spenner (I979, I983, I988, I990: work complexity, control) or even the US Dictionary of Occupational Titles (complexity of dealing with things, people or data) while there may be some agreement, it is difficult to argue that a fundamental advancement has occurred. Indeed, instead of advancing toward some form of integrated analysis we see continued proliferation of labels - most recently emotional work/skill (e.g. Bolton, 2004: Hochschild, I983), articulation work/ skill (e.g. Hampston and Junor, 2005; Strauss, 1985), or aesthetic work/skill (e.g. du Gay, 1996; Nickson, Warhurst, Cullen and Watt, 2003). This is a trend that Keep and Mayhew (1999), Warhurst et al. (2004) and others have registered:

One of the most fundamental changes that has taken place in the last two decades has been the growing tendency to label what in earlier times would have been seen by most as personal characteristics, attitudes, character traits, or predispositions as skills.

(Warhurst et al., 2004: 6)

For policy-makers this trend, of course, produces a measurement problem. But it also sheds light on a real political economic problem for workers and management, and in so doing tells us something more about the nature of skill and the 'skills shortage panic' that afflicts the bulk of OECD countries. It's worth noting, for example, that 'skill' as a personal characteristic or trait, while certainly serving the need for powerful groups to institutionalize their dominance as 'natural', nevertheless limits the penetration of capitalist principles into people's 'lifelong learning' lives. On the other hand, an orientation to personal characteristics or traits as skills extends and deepens the penetration of capital into new terrain including schools, training and, in fact, the everyday life of informal learning as well (see Sawchuk, 2003). That is, left as a personal trait, practice is not subject to the types of competitive commodification 
processes open to intensification (e.g. rising educational attainment, credential inflation): it under-develops the potential of transforming the learning process into a form of capitalist labour process. One way of thinking about the skill shortage panic, then, is that it is less a matter of skill per se, but rather related to the capacity of capital to shape and appropriate latent skill as a competitive advantage; a point which confirms but does not transcend the current consensus on the nature of skill and work.

For theorists, then, this trend has not propelled us any closer to breaking the up-skilling/de-skilling impasse in favour of a critical, integrated analysis. We simply have more concepts to play with. This dove-tails with the tendency that continues today in earnest summarized by Warhurst et al.(2004: 5): ' $[\mathrm{b}]$ ecause skill is difficult to quantify, proxies are used'. Indeed a recent article by Warhurst and Thompson (in press) elaborates on the inadequacies of the 'proxy' approach advocating a new approach focusing on analysis of social practice. They admit that proxies serve important functions but go on to demonstrate how they are increasingly at odds with the evidence; a pattern, they maintain, which also appears to have important ideological dimensions. Certainly, it is frustratingly obvious that the convenience of substituting educational/training credentials for 'skill' (or, likewise, the uncritical use of occupational classification) represents a challenge to construct validity, not infrequently degenerating, as these authors point out, according to the maxim 'what is easy to count gets counted and what is not gets ignored' (2004: IO). Analyses of actual social practices associated with skilled and knowledgeable behavior, show that skill is difficult to quantify particularly on an individual basis, but this begs important questions that emphasize the need to maintain a critical political economic perspective: not simply, why exactly do we need to quantify skill, but also what does this widely held need implicitly say about what we see as relevant and legitimate? Answers to these types of questions reveal many of the crucial but frequently unarticulated presumptions that frame both past and current analysis of skill, particularly in the policy-oriented tradition of 'competence' and 'key skills' analysis (see Payne, I999). That is, clearly, the motive is embedded in the need for productivity, but productivity of a profitable kind; it is embedded in the need for competitive national firms, but competition under certain auspices; it is embedded in the need to engage and reward people, but people constructed as individuals vis-à-vis a labour market; ultimately it is embedded in the need by one social group to control and appropriate the efforts of others.

It is important to map the history of the debate in this way to establish the rationale for the argument I make in the remainder of the article. Specifically, beginning from this foundation I claim the substance of this debate is in several key ways limiting - serving well the occasional degeneration of discussions among researchers into partisan game-playing (see Thompson, $\mathrm{I} 989$ for a discussion of examples). In other words, there is something missing; something that is perhaps fundamental to the development of new pathways toward understanding the nature of skill and work. This something is a specific model of individual and collective human development as a cultural-historically situated 
activity immersed in political economic conditions of capitalism, driven and unified by the key contradictions this system imparts.

This goal of introducing a human development perspective into the labour/ learning process debate begins (but does not end) with the point of contact between, on the one hand, the structure of capitalism, and on the other an analysis of actual processes of individual and collective human change and the workplace. That is, an analysis that allows us to clearly see relational change inclusive of individual mental life and behaviour through to group and organizational shifts all as subject to a broader theory of social struggle and historical change.

The early entry points for such conceptualizations have been developed in a number of key works of the LPT tradition which stand out. Their shared, defining feature is that each has taken seriously the most basic structural element of capitalism itself, the dialectic constitution of the commodity form from which the contradictory elements of the entire circuit of production to consumption and back again is made. The constructive critiques of Braverman, from Burawoy (I979), Friedman (e.g. I977) and Littler (1982), were among the first to outline a dialectic of conflict/consent, control/resistance, bureaucracy/creativity. Indeed, Littler's attention to 'collective organization' including cultural dynamics of custom and tradition are of particular interest. Likewise, Cressey and MacInnes (I980) were among the first (besides Braverman) to explicitly relate LPT dialectically to relations of labour/capital as a whole; these contradictory elements remain, under capitalism, mutually constituting and the primary means through which the historical system undergoes change. This is the point that forms the conceptual core of my argument for new integrated interpretations of skill and work.

\section{New Resources for a Critical Perspective on the Labour/ Learning Process}

I argue that despite the development of vital new concepts and expansive programs of empirical research, our broader understanding of work and learning, and specifically the LPT tradition, has advanced only modestly. In this section I review several key works that, in my view, make fundamental contributions toward the breaking of the up-skilling/de-skilling impasse. Most do so by articulating Marxist principles explicitly, but all point toward key contradictory relationships within work and learning environments that in my view are central to creating a critical, integrated analysis that culminates in my advocacy for a Use-value Thesis and a specific theoretical tradition that encourages a deeper, integrated appreciation of skill, knowledge and learning processes.

Adler (2006) summarizes a good deal of his substantial past work on LPT highlighting the confusion that surrounds the up-skilling/re-skilling debates. In particular he takes the LPT corpus to task for, on the one hand, failing to account for aggregate upgrading trends in education and work-based skill requirements (a product, it is argued, of neo-Marxist fixation on class conflict), 
and on the other, for the drift toward an apolitical, contingency approach and the abandonment of Marxist analysis altogether. Citing the work of Spenner and others, Adler highlights evidence of persistent and persuasively established up-skilling trends drawing on Dictionary of Occupational Titles tracking as well as the massive growth in educational participation over the last 50 years in the US. Though there are some significant clarifications to be made in this regard, ${ }^{3}$ nevertheless, drawing on detailed analysis of global software design work, Adler's goal is more fundamental. He offers a 'paleo-Marxist' (his term) solution to the up-skilling/de-skilling impasse - able to reconcile both a broad pattern of upgrading and a multitude of counter-examples of de-skilling - with a focus on the socialization of the forces of production in a contradictory relationship with the profit-motive of capital and standing relations of production. In other words, an aggregate socialization of work processes (i.e. the expansion of the complexity of the social and technical division of labour) on the one hand, and the expansion of the privatized relations of production (i.e. private ownership and its requirements for capital accumulation) on the other, continually act on one another to produce the types of skill changes Marx originally identified with the transformation of capitalism in terms of the growing capacity of workers to not only produce but to communicate, coordinate and co-operate. He contrasts the apparent 'de-skilling' of software design work through modularization, profit-maximization and globalization, with the overall socialization and growing interdependence that such global production systems necessarily produce, decreasing the 'idiocy' of isolated and particularistic design. In doing this, Adler adds a vital, often forsaken component of LPT by reclaiming the argument that, according to Marx, the forces and relations under capitalism create conditions for historical change because they are contradictory. A reading of either the up-skilling or de-skilling research demonstrates an all too infrequent recognition of this dialectical element; and hence its tendency to under-achieve as an overall analysis of a social, political system in motion.

Complementing Adler's analysis is the work of Nancy Jackson (I994). She presents a fundamental critique of the presumptions that pervade dominant understandings of vocational skill which can serve as an orienting backdrop to the types of gaps produced both in the context of the up-skilling/de-skilling impasse and the otherwise expansive critique offered by Adler. She comments that these dominant understandings,

[treat] knowledge and skill as naturally occurring phenomena, locatable empirically by examination of work processes in the world around us. In this mode, vocational knowledge and skills are constructed as stable objects which stand outside the learner, and can be discovered in the form of 'tasks' to be mastered. Such tasks and their mastery are seen to be unambiguously definable and accessible to evaluation in a systematic and unambiguous manner... 'Performance' becomes a form of action from which the 'knowing subject' has been removed for all practical purposes. It is a moment of abstraction, a separation of subject and object, a rupture in the internal continuity of knowledge and action. It is precisely this separation that provides for the possibility of external definition and control - it creates a position for authority outside the moments of teaching and learning from which these activities may be 
defined, measured, and evaluated for someone else's purposes... But I will argue here that it [also] has the effect of disorganizing vocational activity for the purposes of the individuals whose 'need' is to master it as a form of practical action. (Jackson, I 994: 344)

The key issues raised by Jackson, for our discussion, are (i) the dearth of conceptual means to draw distinctions between managerial/designer based understandings of vocational knowledge and the actual, practical work, skill and knowledge activity, (ii) the persistent, fundamental epistemological denial of the acting and knowing subject, and finally (iii) the socially reproductive effects that these dominant presumptions actually have in 'disorganizing' the potential of workers to individually/collectively work, learn and develop in their own terms. Influenced by the Marxist-feminist sociology of Dorothy Smith, Jackson argues for an analysis that recovers people as subjects of their labour, rather than merely objects of control. She concludes by advocating a variety of socio-cultural schools of thought - among them Cultural Historical Activity Theory - as an important foundation for more adequate analysis of skill and knowledge development.

While not a comprehensive response to the issues raised by Jackson, one hopeful contribution toward a substantive model of skill itself is found in work of A. Aneesh where it's argued that,

[t]here is a need to reconceptualize [Braverman's] thesis about skills and develop new criteria for the understanding of skills. I seek to lift the debate out of the de-skilling vs. re-skilling confusion, developing an alternate set of analytical tools to make sense of skills, especially in view of the transformations associated with information technologies. I attempt to focus on deeper structures of skills independent of the question of whether de-skilling plagues all industries... The concept of skill saturation seeks to evaluate skills solely on the basis of their grammar and structures... It does not allude to the consciousness - obscure or obvious - of the manager or the worker, nor does it refer skills to the will of the work designers... (Aneesh, 200 I: $365^{-6}$ )

This analysis of saturated versus unsaturated skill is well-worth noting. Skill saturation is defined by Aneesh as the closure of the space for play leading to predictability of procedure and outcome 'resulting from the exhaustive ordering of various components of skill and the elimination of all irregular spaces of work' (2001:363-4). Unsaturated skills, on the other hand,

...tend to contain multiple bonds with the job and certain unanalyzed dimensions to allow enough room for action to take place, an action based on long and intuitive understanding. It implies engagement that is implicit, inherent, and defies clear visibility. Michael Polanyi's concept of 'tacit dimension' may allow us to understand how the unqualified process of the formalization of skills leads to complete predictability, and eliminates the elements of creative freedom and discovery. Polanyi explained tacit dimension as something that remains unanalyzable in action.... Many creative skills are performed and learned by 'indwelling' and 'interiorization,' rather than by explicit, formalized knowledge. (Aneesh, 200I: 373-4)

Importantly, Aneesh's model helps us break open some of the contradictory claims that permeate the up-skilling/de-skilling impasse, providing a means 
of more adequately theorizing Jackson's acting/knowing subject for example. His model helps us see that the type of skilled, semi-skilled and un-skilled categorizations of a coding system like the Dictionary of Occupational Titles may in fact miss a crucial point. Many jobs, conventionally defined, may exhibit unexpected levels of botb closure and openness as defined by the 'saturatedunsaturated' continuum, particularly when actual work activity is looked at closely in such a way as to reveal both its conscious and tacit dimensions (see Sawchuk, 2003, Chapter 4). This breaking up of conventional, presumed hierarchies of skill/knowledge is helped further by challenging the arbitrary straight-jacket that defines legitimized goals, interests and activity from a strictly organizational standpoint. ${ }^{4}$ Thus, work that is formally deemed to be highly skilled may at moments exhibit enormously 'saturated' elements, just as apparently unskilled, routinized work frequently obscure enormous evidence of play, hidden 'tricks-of-the trade' and subversion. In fact, the corpus of work/ skill ethnography suggests exactly these forms of contradictory complexity. At the same time, it will be apparent that there is an instructive contrast between Aneesh's and Jackson's assessments: Aneesh's eschewing of the importance of particular social standpoints, his claim of saturation as a more substantive means of identifying de-skilling, and its effect of regularizing work on the one hand, and Jackson's argument for the centrality of recognizing social standpoints and her claim that managerial control and objectification may actually disorganize work/learning activity on the other. How are we to reconcile these seemingly contradictory accounts while maintaining the kind of critical, political economic perspective that Adler calls for?

From the field of educational studies comes a unifying conceptualization that begins to help us address such questions. Glenn Rikowski (e.g. 2002a, $2002 \mathrm{~b}$ ) begins from Marxist theory and expands the issue of skill, education, training and informal learning to all work-based activity as examples of a singular phenomenon: the linkage of labour-power and the notion of personhood:

...labour-power is a complex phenomenon with inherent contradictions and tensions that become incorporated within personhood - given labour-power's fusion with the person of the labourer... However, as well as these diverse aspects of the unified social force that is labour-power, there is a deeper rift that de-stabilises labour-power and the person within which its force flows. Labour-power, which takes the form of human capital, is at odds with the person (de facto with itself) as not-labour-power; the person with interests, desires, motives (with dreams even) that run counter to the subsumption of the self as labour-power. The antagonistic labour-capital relation is a relation within personhood too in capitalist society. Our existence as labour against capital (as opposed to labour within and as capital) places a limit on the capitalisation of our souls...

(Rikowski, 2002a: I 5-I6)

Rikowski (2002b) goes on to list an exhaustive series of qualities, attributes and aspects of labour-power, and recovers Marx's original claims of its singularly unique ability (against all other commodities) to create value, and in the process helps us identify this contested, core relationship: 'The labour-power of the labourer is under the sway of a potentially hostile will, a will that also exists 
against capital as well as within it. The labourers also have the capacity to use their precious commodity in non-capitalist productive forms as labour beyond capital, which is the capitalist's dread' (2002a: 8).

\section{Unifying the Critique: A 'Use-Value Thesis'}

Rikowski's recovery of core principles of Marxist analysis appears to contribute to the type of 'paleo-Marxist' goals identified by Adler in his constructive critique of LPT and de-skilling. Specifically, it recognizes the dialectic nature of skill/knowledge under global capitalism that might help break the impasse of the up-skilling/de-skilling debates without the abandonment of a critical Marxist perspective. A Use-value Thesis begins with this dialectic, rooted in an analysis of the basic building block of capitalist society: the commodity form. We start, first, from the idea that central to understanding the functioning of (past, present or future) society is that people are both, as in Jackson's argument, subjects and objects of history; that societies are actively built. Through this building (or labour) process they satisfy their individual and collective (cultural, psychological and material) needs. In a capitalist society specifically these needs are met in two basic ways: directly (the production of use-values) and indirectly (the production of exchange-values). Use-values are produced all around us, across all spheres of our daily lives, even though only a select portion of this production has legitimized 'economic' value (i.e. exchange-value). Use-value, of course, also provides the basis for commodity production in that consumers buy things that they want to (in some broad sense) use. One of the defining features of capitalist society, as Marx observed, is that as the system develops and expands, more and more of our use-value production is organized by the principle of exchange-value production. In other words, life activities are increasingly commodified. ${ }^{5}$ This expresses the basic contradiction between the forces (socio-technical configurations which include learning, skill and knowledge) and relations (premised on inter-capitalist competition, the appropriation of surplus value and hence antagonistic class forms) of production. My point here is that use-value production is the foundational activity, and must be actively reconfirmed to better understand the complexity and specificity of work/learning practice.

Activity, skill and knowledge embedded in use-value production accounts for the pragmatic, shared, and generally co-operative orientation by both workers and management toward the intrinsic, practical usefulness of the service or product. In fact, use-value orientation also explains much of the shared interest in maintaining a reasonable environment of human interrelation (i.e. use-value in terms of friendship, recognition, respect, identity formation, etc.). This largely supports aspects of the original observations found in Burawoy (1979). However none of this precludes the conflict that necessarily emerges as use-value generation comes into relationship with the over-arching need to generate ever increasing levels of exchange-value and profit, in the classic analysis of antagonistic relations of production, subversion, resistance, sabo- 
tage and so on (e.g. Ackroyd and Thompson, I999; Roscigno and Hodson, 2004). As Hampson and Junor put it,

'Work' does not mean only 'hard labour' ('ponos'), since work can sometimes become 'play'. Equally, a diversity of forms of action like play, games, casual conversation, expressive action, emotional action and symbolic action (like the devotional, the sacrificial, the sacred) is, at times, at least partially constituted by 'work'. (2005: I68)

Likewise, Korczynski (2002) comes very close to this basic analysis in recognizing the 'contradictions' that undermine any simple dichotomy of 'good' and 'bad' work. Workers do find joy and engagement as well as conflict, stress, frustration and alienation, as he notes, making for a 'fragile social order'. What Korczynski does not register is that this fragility has systematic roots in the contradiction between use-value and exchange-value dimensions of organizational life, specific in its form to capitalism.

The Use-value Thesis, in this sense, places this type of contradictory 'parallel universe' that prevails in all capitalist workplaces at the centre of work/skill analysis. This central contradiction anticipates varying degrees of both cooperation and conflict, both engagement and alienation, both up-skilling and de-skilling simultaneously within the same work environment. As a summary across the research attests, with particular attention to the foundation established by the work of Burawoy, such dynamics simply are not mutually exclusive, and the Use-value Thesis, in this sense, contributes a unifying explanation why, under capitalism, this is necessarily the case.

The work of the four authors reviewed above can be understood in relation to this dialectic of use-value/exchange value. For this, we can pay particular attention to their discussions of distinctive contradictory relations (roughly summarized for each author as follows):

- Socialization of Forces of Production versus the Relations of Production and Capitalist Profitability (Adler):

- Practical Action/Knowing Subjects versus Objectifying Managerial Control (Jackson):

- Unsaturated Skill/Play versus Saturated Skill/Rationalized Procedure (Aneesh): and

- Labour-Against-Capital versus Labour-As-Capital (Rikowski).

The linkage between work and learning as understood by a Use-value Thesis is inherent in, as Rikowski puts it, 'labour-power's fusion with the person'. Learning, as I comment elsewhere, is the labour we do on ourselves and this labouring also teaches us whether this learning is deemed legitimate or not. Given that labour is constituted by both use-value and exchange-value production we can speak in the same terms of learning. Of course, as valuable as it may be to raise the questions and issues above, there is still a good deal missing regarding tools for a coherent empirical program and synthesis. In this sense, both Jackson's (1994) and Adler's (2006) explicit suggestions for a turn toward socio-cultural approaches to learning are relevant.

The lack of attention to actual processes of human development and activity, 
and the lack of attention to the 'knowing and acting subject' within analyses of the labour process appears chronic; a condition which virtually assures the maintenance of the up-skilling/de-skilling impasse on the one hand, and the tendency to 'de-Marxify' LPT on the other. Likewise, the obfuscating and persistent characterizations of so-called 'optimistic' or 'pessimistic' approaches to skill in many ways signal that the up-skilling/de-skilling impasse is holding firm.

How does the Use-value Thesis open up new ground for integrated LPT research? It does so by, first, inherently linking labour process and labourpower concepts to socio-cultural theoretical traditions such as CHAT that have the capacity to offer detailed, expansive, empirical analyses of the actual human developmental process. Second, it provides the capacity to identify and track interwoven 'trajectories of activity' (i.e. learning and human development; Sawchuk, 2003) that always co-exist but which account for radically different expansive and/or restrictive learning environments and outcomes. Drawing on Aneesh's (200I) formulation, for example, while a set of occupational skills may be assessed as leaning toward the saturated end of his 'saturated-unsaturated' continuum model (leaving little room for discretion and play) this may simply be accurate for those activities defined as organizationally legitimate, that is involving processes that convert labour-power into surplus value and ultimately exchange-value and profitability. If we are to pay attention to Marx, as Adler and Rikowski do, we might recognize the importance of actively registering the dialectic of exchange-value and use-value production.

\section{Implications of the Use-value Thesis}

It may seem odd that 'use-value' appears to take centre-stage in my argument, but this is a matter of strategic emphasis and an interest to frame the labour process historically. After all, at a basic level, the idea of exchangevalue oriented production hardly needs to be explained. It is the production of exchange-value that (quite logically under capitalism) governs the majority of practical planning, design and control within the institution of paid work. Whatever the specific issues of contention, how many times have industrial relations conflicts pivoted on the question: If the firm doesn't survive, what's the point? Both workers and management explicitly recognize this principle, even if the former occasionally resist and challenge it. Thus, the orientation to exchange-value production is explicitly established-logically, legally, culturally and bureaucratically - by the very nature of the enterprise. Not withstanding, what is equally true is the fact that across historical epochs and political economic arrangements prior to and beyond capitalism, use-value production is the common, continuous activity; a point (somewhat differently) made by Tinker (2002: 27I) in his discussion of Braverman. I argue that no analysis of the labour process is complete without these recognitions. This, in turns, helps us establish the dynamic of contradictions and that in placing the relationship of use-value and exchange-value at the centre of our understanding of work, 
we have a coherent way of theorizing why and how conflict and co-operation, enchantment and alienation, de-skilling and up-skilling necessarily co-exist, and their relationship with historical change.

An important implication of the Use-value Thesis - the one most directly apposite to analyses of work-based skill and knowledge - is that by foregrounding this particular contradiction we can readily extend our analyses of work and political economy to the type of robust theories of learning and human development advocated, implicitly and explicitly in my discussion of 'new resources' earlier. This brings us to the necessary relationships between notions of contradiction and theories of learning. I anticipate that not all readers will be familiar with the corpus of adult learning theory as such, but today the most powerful analyses are 'socio-cultural' in nature (see Fenwick, 200 I; Sawchuk, $20032006 \mathrm{~b}$, in press), and in particular it is theories of activity or CHAT that stand out in terms of their integration of issues of human development with notions of systemic contradiction endemic to capitalism. A quick look at the recent skills literature (e.g. the collection by Warhurst et al., 2004), reveals a referential knowledge of the likes of Lave and Wenger, Barley and Orr. These authors contribute important elements to many sociology of work and LPT efforts. However, important gaps remain in comparison to CHAT perspectives: namely, the vacuum in terms of any substantive integration of critical, political economic elements. Lave and Wenger (199I), for example, upholds the principle that the core dynamic of legitimate peripheral participation is the humanist struggle between experts and novices. The notion of conflict in its broader social forms - forms that deeply shape the nature of capitalist workplace - are simply not there (see Sawchuk, 2003).

Space does not permit a full elaboration and demonstration of the CHAT approach to learning and work (for this see Chaiklin, Hedegaard and Jensen, I999; Engeström, 1987, 1990, 2001; Engeström and Middleton, I996; Engeström, Miettinen and Punamäki, I999; Nardi, I996; Robbins and Stetsenko, 2002; and for more explicitly politicized applications Gairey, $\mathrm{Ng}$, Martin and Jackson, 2004; Livingstone and Sawchuk, 2004; Sawchuk, 2003; Sawchuk, Duarte and Elhammoumi, 2006; Worthen, 200I). Nevertheless, a basic orientation is important to begin to appreciate the implications of the Use-value Thesis. The origins of the CHAT tradition lie in the radical critique by two of psychology's core historical figures, Lev Vygotsky (I896-I934) and Aleksei Leont'ev (I903-1979), who together challenged individualized (and apolitical) models of human development by establishing an understanding of how external social-material relations of participation are inseparable from, but also functionally primary to, individual skill and knowledge capacity. Against the post-structuralist critique of Braverman LPT that, with relatively little theoretically sophisticated challenge established a veritable monopoly over questions of the individual, CHAT offers a deeply human, historical and materialist response to questions of self. ${ }^{6}$

CHAT offers a non-reductionist ontological vision of human nature and development as being rooted in material social practices that, on the one hand, produce and 
engender social interactions and human subjectivity, and, on the other hand, are themselves reciprocally produced by these interactions and subjectivity. (Stetsenko and Arievitch, 2004: 496)

Learning, in the CHAT tradition, is defined as activity. What most people think of as individual skill and knowledgeability, in the conventional sense, is the natural byproduct and currency of activity. The concept of activity - the system through which individuals and groups engage in social action mediated by tools, symbols/discourses, rules and divisions of labour - is argued to be the minimal, meaningful unit of analysis of human development. CHAT maintains that activity systems include the broader social-structural motives (e.g. the broader relations and forces of production), self-conscious goals and action (e.g. work tasks), as well as tacit operations (e.g. the local social and material conditions and practices of accomplishment). Importantly, this transcends the boundaries of the many, proliferating approaches to the learning process including modifiers such as formal, informal, experiential, self-directed, reflective and tacit.

This conceptualization of levels of activity has important implications in its own right. Of course, a variety of analytic traditions - including Polanyi, Garfinkel, Goffman, Bourdieu and in some sense even Freud, to name only a few diverse examples - have noted that people's conscious accounts of their own practice only address a proportion of their practice and capacity for practice as a whole. CHAT has been clear from the beginning that practice related to the motive and operation levels of activity are not typically conscious and available for discursive account. Without intervention of some sort, it is only the object/goal level of activity to which people have conscious access. Obviously, either interview or survey instruments unaware of this basic fact are particularly vulnerable to the type of validity problems rooted in 'proxy' inferences. This applies to people's own accounts of skilled and knowledgeable practice, and leaves interviewees/respondents with only the (web of) discourses available to them on which to base their response. Warhurst et al. (2004: I I-I 2) have summarized this basic discursive dimension of skill as a 'rhetorical device' that can be both benign and misleading. However, in applying a CHAT analysis, for example, to the issue of discretion on the job, we can begin to see a range of forms of choice that neither workers, management, nor researchers typically register. From a CHAT perspective, discretion should be assessed at all levels of activity including: I) the mediating artifacts, tools, technologies and discourses of production; 2) conditions of production; 3) objective or goals of production; and finally 4) the motive structure of production. This approach further develops our understanding of the basic critiques, for example, of the quality movement, teamwork, empowerment programs or even high performance production systems, as examples of constrained freedom (see Edwards and Collinson, 2002; Hales, 2000; Thompson, 2003). The fact is that, against all these dimensions of possible discretion, research instruments tend to report only on number three (the object/goals of activity) suggesting, at the very least, conservative evaluations. The quantitative research that perhaps comes the 
closest to accessing this information can be seen in the UK Skills Surveys discussed in Felstead, Gallie and Green (2004) where they ask, for example: 'How much influence do you personally have on... how hard you work; deciding what tasks you are to do; deciding how you are to do the task; and deciding the quality standards to which you work?' Leaving aside the important issues of 'personal' versus 'collective' control (i.e. as an individual versus as a member of a team, department or union), the lack of any comparators for the assessments (i.e. a 'great deal' of discretion in comparison to what exactly?), and the need for broader attention to the full range of mediations that shape participation, the question does begin to address the motive, object and operation levels generally, even if, in the end, it necessarily relies on self-conscious accounts of the respondent. Thus, in this discussion of implications, I can add that - while qualitative and specifically ethnographic methods are typical for this type of analysis - my point is certainly not to critique survey instruments, but rather to call for expanded modes of interpretation. As Adler has pointed out, 'defining and understanding skill is... a difficult task - and empirical data often do not resolve the problem' (2004: 242).

Most central to my argument in this article, however, is that the CHAT tradition demonstrates that the motor for development is the experience and resolution of contradictions endemic to particular, empirically available, activity systems that constitute the labour process. Development is understood as interactive mismatches between the motives, actions and operations, on the one hand, and the many forms of mediation through which people act, on the other. This allows skill and knowledge analysis to be systematically incorporated as part of the series of systemic tensions, problems and opportunities that describe the dynamic nature of work organization. In addition, contradictions, according to the most prominent, contemporary voice in the CHAT tradition, Engeström (1987; see Engeström, 200 I for a general introduction), can be distinguished in a number of ways. Secondary and tertiary contradictions, for example, refer to those rooted in role conflict in work teams or communications inadequacies on an organizational level. These types of contradictions, it is important to note, are deeply interwoven with but not necessarily unique to paid work or capitalism and express broader, and in a sense more fundamental, historical processes (e.g. in terms of contradictions expressing racial or gender divisions). Unique to capitalism, however, are primary contradictions which Engeström explains, following Marx, are rooted in the commodity form: the dialectic constitution of use-value and exchange-value production. Indeed, this is precisely where the research of Adler, Jackson, Aneesh and Rikowski fit: in their detailed examples of each type of contradiction. Moreover, with a focus on this primary contradiction, what I refer to as 'trajectories of activity' can be analytically distinguished: minimally, trajectories of activity and change that foment and affirm exchange-value over use-value generation, and the reverse, trajectories of activity that partially resolve the primary contradiction by affirming and developing use-value irrespective of exchange-value. The dominance of one over the other defines either restrictive or expansive learning 
environments. In either case, conceptualizing these trajectories describes interwoven patterns of individual and collective human development - inclusive of formalized training, informal learning, intentional and tacit learning as well as the proliferating forms of skill the research has continued to throw forward - and allows us to understand, and indeed partially predict, the specific forms of skill and knowledge that emerge, even in the case where they appear superficially as a 'failure to learn' (there is in fact no such thing - there is only a failure to learn some things as opposed to others).

In summary, if as is claimed learning occurs through the resolution of various contradictions, it not only behoves us to recognize its most primary form (use-value/exchange-value relations), but in so doing it allows us to empirically link the labour process with more robust analyses of actual human development. This represents a level of analysis that remains largely implicit in sociology of work and LPT currently; implicitness that contributes significantly to what I've termed the 'up-skilling/de-skilling impasse'. Sociology of work and LPT offer enormously important empirical clarification of many key elements central to a CHAT approach to work-based learning including detailed descriptions of changing divisions of labour, technologies of production and control, communal norms/traditions, and so on. Industrial relations, in turn, provides invaluable material on the interactions between key activity systems (e.g. the relations between the state, business and unions, for example), key mediating artifacts such as collective agreements, labour relations policy, discourses on team-work, quality, empowerment, and so on. The Use-value Thesis has the potential to help integrate much of this research.

\section{Conclusion}

The Use-value Thesis, while exploratory and preliminary, hopefully does not appear completely alien. If it does, perhaps this is because it emerged, in the first instance, from an empirical-theoretical focus on the skill and knowledge development process which, in turn, required and has benefited from detailed analysis of work, rather than the other way around. As Adler (2004: 258) points out, "[a] good theory of skill is needed. A paleo-Marxist version of labour process theory is a promising starting point'. For the purposes of better understanding the labour process and the local learning responses of workers, the proposed marriage of ideas encourages the maintenance of a critical, political economic perspective while incorporating the power of robust theories of human development. It theorizes the juxtaposition of widespread de-skilling, on the one hand, and, what becomes increasingly clear at another level, that worker/management co-operation does exist and that, in fact, new skills are constantly emerging. Conventionally, these new skills refer to those necessary for working within new labour processes and emergent sectors, but the Use-value Thesis also helps to bring into focus the new skills for working around restrictive work systems that can be either new or well established. Up-skilling must be understood in this dual sense, as including both those skills that 
management hopes for and legitimizes, and the skills of 'making out', 7 disengagement and resistance that they do not. Against this observation, de-skilling can be understood on conceptually different plane; a process revolving around autonomy/control and not skill per se. It is a concept that theorizes formal disempowerment, appropriation and, in a wider sense, cultural disinheritance, as old skills forms are displaced and the new ones that emerge are both limited and limiting in terms of anything but exchange-value generation.

Thus, in the narrow terms of actual human skill there really is no such thing as de-skilling: from both CHAT and a variety of other perspectives, skills emerge wherever people engage in activity, and they include the many skills that are central to production, not (yet) appropriate-able by capital and those that management rejects altogether. The up-skilling and de-skilling debate is, therefore, fuelled by researchers referring to fundamentally different frames of reference and presumptions. Up-skilling advocates presume 'labour-powerfor-capital' as the legitimate arena of skill analysis, while happily taking up the proliferating classification of previously un-identified forms (emotional, aesthetic, articulation skills, and so on) as proof of its adequacy. At its worst this perspective leads to a notion of skill that is dangerously close to, as Lafer (2004: I 8 ) puts it, "nothing more than "whatever employers want". ${ }^{8}$ De-skilling advocates, on the other hand, presume that individual and collective freedom, power and control over their myriad skills is the point, inherently questioning the legitimacy of capitalist relations of production.

Obviously, however, it is the notion of contradictory, mutually constituting relations that is central to the proposed mode of analysis, and herein I have explored new conceptual resources for specifying these relations. The work of the authors I reviewed each illuminate a key form, all of which can be seen to contribute to understanding the 'parallel universes' that make up the labour process and human development within the capitalist workplace. Clearly, broader trends toward collective socialization occur even amidst global, modularization of production (Adler). Subjects demonstrate their agency even under conditions of objectification and rationalization that, as an expression of exchange-value orientation, can at times 'disorganize' production (Jackson). De-skilling undoubtedly occurs as pockets of skills become 'saturated', even in professional settings where we might not conventionally expect it, and upskilling occurs, even within routine work where sometimes the only spaces for creativity, play and 'unsaturated' knowledge (Aneesh) are found in forms of resistance. And, perhaps most fundamental of all, learning, skill and knowledge must be understood as the contradictory development of labour power where capital can both colonize the personhood of the worker and, still, there is room for opposition (Rikowski).

Drawing on these and other conceptualizations, the Use-value Thesis allows the linkage of critical labour process analysis to robust theories and empirical work that show in detail the human developmental activity that underlie the de facto and proxy references to skill and knowledge. Setting aside the obvious value of current sociology of work and LPT research, the ability to document 
the performance of the vast array of different skills, or even the ability to distinguish skilled versus unskilled performance shouldn't be allowed to stand in for understanding the dynamic processes concerning how these skills, knowledge and performances actually emerge. We are faced with a choice then: continue to name an ever proliferating set of work/skill types and simply correlate their appearance with different elements of labour process; or, we can turn toward a unified analysis that does not abandon the solid research on up-skilling and de-skilling but rather demonstrates how political economy, the labour process and the learning process can be understood within the same unit of analysis.

In the context of my critical appraisal of the up-skilling/de-skilling impasse, how contradictory this situation is: de-skilling and up-skilling all at once, despite the fact that a great deal of learning is not necessarily what either management or up-skilling advocates had in mind. Across both up-skilling and de-skilling, actual changes in human development pivot on the types of contradictions outlined by Adler, Jackson, Aneesh and Rikowski. However, an emphasis on the contradiction of use-value and exchange-value remains central to understanding the interwoven trajectories of learning. That is, drawing on a CHAT analysis, all individuals can be seen to be engaged in learning in order to satisfy their direct human needs (use-value) which is nevertheless analytically distinguishable from, and necessarily in contradiction with, the learning that leads directly to the realization of exchange-value, profitability and privately owned and/or controlled capital. This is the unity of use-value and exchangevalue production as work-based learning. This call for an integrated model of the labour/learning process is about more than building a conception of 'how' skills appear. Understanding 'how' is a stepping stone to understanding that the 'sticking points' for developing a genuine knowledge economy are to found in the type of contradictions of the labour/learning process I've begun to explore here. ${ }^{9}$

\section{Notes}

I Project funded by SSHRC-INE under the Working and Lifelong Learning Network, entitled the 'Working IT Project' (Principal Investigator, Peter H. Sawchuk). An initial introduction and analysis is available in Hennessy and Sawchuk (2003).

2 Braverman noted that, on the one hand, many so-called unskilled jobs were in fact skilled jobs (in particular he mentions farm work, the decline of which was assumed to signal an aggregate skills upgrading); and on the other the hand, many contemporary jobs were mis-labeled as semi-skilled or skilled simply because of their title and authority, or because they use newer technology.

3 These clarifications include that fact that the US Dictionary of Occupational Titles is far from a definitive assessment of actual skill and knowledgeability of workers in practice. Its use represents the challenges of proxy inferences. The latest version results from fairly cursory occupational analysis (indeed, the classification systems in the $4^{\text {th }}$, $5^{\text {th }}$ and 6th digits of the codes are laughable if one were to compare them to even the most basic qualitative accounts of workers and work). Moreover, as Livingstone [1999; and Berg (1970) and Perrow (I986) before him] has demonstrated, increased educational participation may in fact be better termed 'credential inflation' in that there clearly exists a series of 'gaps' between skill/knowledge acquisition and application in the labour 
process. See also the brief commentary on this matter in Warhurst, Grugulis and Keep (2004: IO-I I).

4 Such 'organizational standpoints' would include a bloc of dominant interests, minimally based on gender and race as well as class positions.

5 The key examples here are, of course, the idea of 'human capital' as well as the notion of 'soft skills' and the host of newly identified work/skill forms. These concepts function to convert activities, skills and knowledge broadly conceived into things that (may) have value in exchange (e.g. for a wage).

6 As has been noted earlier in the article, Braverman consciously left to one side questions related to the subjective experience of work. Researchers since Braverman, notably Burawoy but others as well, responded, but without a robust empirical-theoretical approach to the relationship between consciousness, the individual, the social, the material and the historical. Along with Braverman's initial omission, this vacuum helped pave the way for the post-structuralist critique. As I try to explain in Sawchuk (2003, 2006b), the Vygotskian notion of mediation is a crucial means of thinking of the individual as socially, materially and historically situated, yet agentive (see Stetsenko and Arievitch, 2004); fundamentally different from post-structuralism as well as liberal humanism in its approach. In Sawchuk (2006a) I explain this perspective in terms of different, contradictory forms of worker consciousness.

7 'Making out', the framing of work activity as a 'game' are of course terms brought forth in the works of Roy and later Burawoy where they represent a coping mechanism that, as Vallas (200I: 443) puts it, describes the construction of an 'imaginary realm of freedom on the shopfloor'; a construct that requires an array of forms of situated, individual and collective development.

8 A point not that far off Braverman's own recognition that, as Tinker (2002: 275) pointed out, 'skill' had come to mean 'waged work that is productive of surplus value'.

9 The policy implications of this approach are roughly aligned with those outlined in Keep (2000a, 2000b).

\section{References}

Ackroyd, S. and Thompson, P. (r 999) Organisational (Mis)Behaviour. London: Sage.

Adler, P. (2004) 'Skill Trends Under Capitalism and the Socialisation of Production', in C. Warhurst, I. Grugulis and E. Keep (eds) The Skills that Matter, pp.242-6o. London: Palgrave Macmillan.

Adler, P. (2006) 'From Labour Process to Activity Theory', in P. Sawchuk , N. Duarte and M. Elhammoumi (eds) Critical Perspectives on Activity: Explorations Across Education, Work and Everyday Life, pp.225-6r. New York: Cambridge University Press.

Aneesh, A. (200I) 'Skill Saturation: Rationalization and Post-industrial Work', Theory and Society $30(3): 363-96$.

Attewell, P. (I987) 'The De-skilling Controversy', Work and Occupations I4(3): 323-46.

Baldry, C., Bain, P. and Taylor, P. (1998) 'Bright Satanic Offices: Intensification, Control and Team Taylorism', in P. Thompson and C. Warhurst (eds) Workplaces of the Future, pp. I63-83. London: Macmillan.

Beirne, M., Ramsay, H. and Pantelli, A. (I 998) 'Developments in Computing Work: Control and Contradiction in the Software Labour Process', in P. Thompson and C. Warhurst (eds) Workplaces of the Future, pp. 142-62. London: Macmillan.

Berg, I. (1970) Education and Jobs: The Great Training Robbery. New York: Praeger.

Blauner, R. (I 964) Alienation and Freedom. Chicago: Chicago University Press.

Bolton, S. (2004) 'Conceptual Confusions: Emotion Work as Skilled Work', in C. Warhurst, 
I. Grugulis and E. Keep (eds) The Skills that Matter, pp.19-37. London: Palgrave Macmillan.

Braverman, H. (1974) Labor and Monopoly Capital: The Degradation of Work in the Twentieth Century. New York: Monthly Review Press.

Burawoy, M. (1979) Manufacturing Consent: Changes in the Labour Process under Monopoly Capitalism. Chicago: University of Chicago Press.

Burawoy, M. (1985) The Politics of Production. London: Verso.

Chaiklin, S., Hedegaard, M. and Jensen, U. (I999) Activity Theory and Social Practice: Cultural Historical Approaches. Århus: Århus University Press.

Cockburn, C. (1985) Machineries of Dominance: Men, Women and Technological Change. London: Pluto Press.

Cressey, P. and MacInnes, J. (I980) 'Voting for Ford: Industrial Democracy and the Control of Labour', Capital \& Class i i: 5-53.

Dahrendorf, R. (1959) Class and Class Conflict in an Industrial Society. London: Routledge \& Kegan Paul.

Du Gay, P. (1996) Consumption and Identity at Work. London: Sage.

Edwards, R. (1979) Contested Terrain: The Transformation of the Workplace in the Twentieth Century. London: Heinemann.

Edwards, P. and Collinson, M. (2002) 'Empowerment and Managerial Labor Strategies: Pragmatism Regained', Work and Occupations 29(3): 272-99.

Engeström, Y. (1987) Learning by Expanding: An Activity-theoretical Approach to Development Research. Helsinki: Orienta-Konsultit.

Engeström, Y. (1990) Learning, Working and Imagining: Twelve Studies in Activity Theory. Helsinki: Orienta-Konsultit.

Engeström, Y. (200I) 'Expansive Learning at Work: Toward an Activity Theoretical Reconceptualization', Fournal of Education and Work I4(I): 133-56.

Engeström, Y. and Middleton, D. (1996) Communication and Cognition at Work. New York: Cambridge University Press.

Engeström, Y., Miettinen, R. and Punamäki, R.-L. (I 999) Perspectives on Activity Theory. New York: Cambridge University Press.

Felstead, A., Gallie, D. and Green, F. (2004) 'Job complexity and task discretion: Tracking the direction of skills at work in Britain', in C. Warhurst, I. Grugulis and E. Keep (eds) The Skills that Matter, pp. I48-69. London: Palgrave Macmillan.

Fenwick, T. (200I) 'Tides of Change: New Themes and Questions in Workplace Learning', New Directions for Adult and Continuing Education $9^{2}$ (winter): $3^{-1} 7$

Form, W., Kaufman, R., Parcel, T. and Wallace, M. (I 988) 'The Impact of Technology on Work Organization and Work Outcomes', in G. Farkas and P. England (eds) Industries, Firms and fobs: Sociological and Economic Approaches, pp.303-328. New York: Plenum.

Frenkel, S., Korczynski, M., Shire, K. and Tam, M. (1999) On the Front Line: Organization of Work in the Information Economy. Ithaca, NY: Cornell University Press.

Friedman, A. (1977) Industry and Labour: Class Struggle at Work and Monopoly Capitalism. London: Macmillan.

Friedmann, G. (I961) The Anatomy of Work. London: Heinemann.

Gairey, J., Ng, W., Martin, D. and Jackson, N. (2004) The Challenge of Education for Equality in Unions. Unpublished Manuscript, Work and Lifelong Learning Network, Centre for the Study of Education and Work, OISE/University of Toronto, Toronto, Canada.

Hales, C. (2000) 'Management and Empowerment Programmes', Work, Employment and Society I4(3): 50 I-5 I9.

Hales, M. (I980) Living Thinkwork: Where do Labour Processes Come From? London: CSE Books. 
Hampson, I. and Junor, A. (2005) 'Invisible Work, Invisible Skills: Interactive Customer Service as Articulation Work', New Technology, Work and Employment 20(2): I66-8I.

Hennessy, T. and Sawchuk,P. (2003) 'Worker Responses to Technological Change in the Canadian Public Sector: Issues of Learning and Labour Process,' fournal of Workplace Learning I 5(7): 319-25.

Hirschhorn, L. (1984) Beyond Mechanization: Work and Technology in a Postindustrial Age. Cambridge, MA: MIT Press.

Hochschild, A. ( 1983 ) The Managed Heart: Commercialisation of Human Feeling. Berkeley, CA: University of California Press.

Jackson, N. (1994) 'Rethinking Vocational Learning: The Case of Clerical skills', in L. Erwin and D. MacLennan (eds) Sociology of Education in Canada: Critical Perspectives on Theory, Research and Practice, pp.34I-5I. Toronto: Copp Clark Longman.

Keep, E. (2000a) 'Creating a Knowledge-driven Economy: Definitions, Challenges and Opportunities', SKOPE Policy Paper No.2, University of Warwick, UK.

Keep, E. (20oob) Upskilling Scotland. Edinburgh: Centre for Scottish Public Policy.

Keep, E. and Mayhew, K. ( I 999) 'The Assessment: Knowledge, Skills, and Competitiveness', Oxford Review of Economic Policy I 5(I): I-I 5.

Kelley, M. (I990) 'New Process Technology, Job Design and Work Organization: A Contingency Model', American Sociological Review 55(2): I9I-208.

Kerr, C., Dunlop, J., Harbison, F. and Myers, C. (1962) Industrialism and Industrial Man. London: Heinemann.

Knights, D. (I990) 'Subjectivity, Power, and the Labour Process', in D. Knights and H. Willmott (eds) Labor Process Theory, pp.297-335. London: Macmillan.

Knights, D. (2000-I) 'Hanging Out the Dirty Washing', International Studies of Management \& Organization $30(4): 68-84$.

Korczynski, M. (2002) Human Resource Management in Service Work. London: Palgrave.

Lafer, G. (2004) 'What is "Skill”? Training for Discipline in the Low-wage Labour Market', in C. Warhurst, I. Grugulis and E. Keep (eds) The Skills that Matter, pp. Io9-1 27. London: Palgrave Macmillan.

Lave, J. and Wenger, E. (199I) Situated Learning: Legitimate Peripheral Participation. New York: Cambridge University Press.

Littler, C. (1982) The Development of the Labour Process in Capitalist Societies: A Comparative Analysis of Work Organization in Britain, the USA and Fapan. London: Heinemann.

Livingstone, D. (1999) The Education-7obs Gap. Toronto: Garamond Press.

Livingstone, D. and Sawchuk, P. (2004) Hidden Knowledge: Organized Labour in the Information Age. Toronto: Garamond Press.

Milkman, R. (1998) 'The New American Workplace: High Road or Low Road?', in P. Thompson and C. Warhurst (eds) Workplaces of the Future, pp.25-39. London: Macmillan.

Nardi, B. (I996) Context and Consciousness: Activity Theory and Human-computer Interaction. Cambridge, MA: MIT Press.

Nickson, D., Warhurst, C., Cullen, A. and Watt, A. (2003) 'Bringing in the Excluded? Aesthetic Labour, Skills and Training in the 'New Economy", fournal of Education and Work I6(2): 185-203.

Nonaka, I. and Takeuchi, H. (1995) The Knowledge-creating Company: How Japanese Companies Create the Dynamics of Innovation. New York: Oxford University Press.

O'Doherty, D. and Willmott, H. (200I) 'Debating Labour Process Theory: The Issue of Subjectivity and the Relevance of Poststructuralism', Sociology 35(2): 457-76.

Parker, M. (I999) 'Capitalism, Subjectivity and Ethics: Debating Labour Process Analysis', Organization Studies 2O(I): 25-45.

Payne, J. (I999) 'All Things to All People: Changing Perceptions of "Skill” among Britain's 
Policy Makers Since the I950's and their Implications', SKOPE Research Paper, No.I, University of Warwick.

Perrow, C. (1986) Complex Organizations: A Critical Essay. New York: Random House

Piore, M. and Sabel, C. (1984) The Second Industrial Divide: Possibilities for Prosperity. New York: Basic Books.

Pollert, A. (1981) Girls, Wives, Factory Lives. London: Macmillan.

Rikowski, G. (2002a) Methods for Researching the Social Production of Labour Power in Capitalism. University College Northampton School of Education Research Seminar (7th March).

Rikowski, G. (2002b) 'Fuel for the Living Fire: Labour-power!', in A. Dinerstein and M. Neary (eds) The Labour Debate: An Investigation into the Theory and Reality of Capitalist Work. Aldershot: Ashgate.

Ritzer, G. (1998) The McDonaldisation Thesis. London: Sage.

Robbins, D. and Stetsenko, A. (2002) Voices within Vygotsky's Non-classical Psychology: Past, Present, Future. New York: Nova Science Publishers.

Roscigno, V. and Hodson, R. (2004) 'The Organizational and Social Foundations of Worker Resistance', American Sociological Review 69(I): I4-39.

Sawchuk, P. (2003) Adult Learning and Technology in Working-Class Life. New York: Cambridge University Press.

Sawchuk, P. (2006a) 'Activity and Power: Everyday Life and Development of Workingclass Groups', in P. Sawchuk , N. Duarte and M. Elhammoumi (eds) Critical Perspectives on Activity: Explorations Across Education, Work and the Everyday, pp.238-67. New York: Cambridge University Press.

Sawchuk, P. (2006b) 'Frameworks for Synthesis of the Field of Adult Learning Theory', in T. Fenwick, T. Nesbit and B. Spencer (eds) Contexts of Adult Education: Canadian Perspective, pp. I40-52. Toronto: Thompson.

Sawchuk, P. (in press) 'Informal Learning and Work: From Genealogy and Definitions to Contemporary Methods and Findings', in R. Maclean and D. Wilson (eds) International Handbook of Technical and Vocational Education and Training, pp.276-300. Dordrecht, Netherlands: Springer Publishers.

Sawchuk, P., Duarte, N. and Elhammoumi, M. (2006) Critical Perspectives on Activity: Explorations Across Education, Work and Everyday Life. New York: Cambridge University Press.

Smith, C., and Thompson, P. (r999) 'Re-evaluating the Labor Process Debate', in M. Wardell, T. Steiger and P. Meiksins (eds) Rethinking the Labor Process, pp.205-232. Albany: State University of New York Press.

Spenner, K. (I979) 'Temporal Changes in Work Content', American Sociological Review 44(6): $968-75$.

Spenner, K. (1983) 'Deciphering Prometheus: Temporal Change in the Skill Level of Work', American Sociological Review 48(6): 824-37.

Spenner, K. (1988) 'Technological Change, Skill Requirements, and Education: The Case for Uncertainty', in R. Cyert and D. Mowery (eds) The Impact of Technological Change on Employment and Economic Growth, pp. I 3 I-84. Cambridge, MA: Ballinger.

Spenner, K. (I990) 'Skill: Meanings, Methods and Measures', Work and Occupations I 7(4): 399-42 I

Storey, J. (I985) 'The means of management control', Sociology I 9(2): I93-2 I I.

Streeck, W. (1989) 'Skills and the Limits of Neo-liberalism: The Enterprise of the Future Place of Learning', Work, Employment and Society $3(\mathrm{I})$ : 89-104.

Stetsenko, A. and Arievitch, I. (2004) 'The Self in Cultural-historical Activity Theory: Reclaiming the Unity of Social and Individual Dimensions of Human Development', Theory of Psychology, I4(4): 475-503. 
Strauss, A. (1985) 'Work and the Division of Labour', The Sociological Quarterly 26(I): I-I9.

Thompson, P. (1989) The Nature of Work: An Introduction to Debates on the Labour Process. London: Macmillan.

Thompson, P. (2003) 'Disconnected Capitalism: Or Why Employers can't Keep their Side of the Bargain', Work, Employment and Society I 7(2): 359-78.

Tinker, T. (2002) 'Spectres of Marx and Braverman in the Twilight of Postmodernist Labour Process Research', Work, Employment and Society I6(2): 25 I-8I.

Touraine, A. (197 I) The Post-Industrial Society: Tomorrow's Social History: Classes, Conflicts and Culture in the Programmed Society. New York: Random House.

Vallas, S. (200I) 'Burawoy's legacy', Contemporary Sociology 30(5): 442-5.

Wardell, M., Steiger, T. and Meiksins, P. (1999) Rethinking the Labor Process. Albany, NY: SUNY Press.

Warhurst, C., Grugulis, I., and Keep, E. (eds) (2004) The Skills that Matter. London: Palgrave Macmillan.

Warhurst, C. and Thompson, P. (in press) 'Mapping Knowledge in Work: Proxies or Practices?' Work, Employment and Society, 20(4).

Westwood, S. (1984) All Day Every Day: Factory and Family in the Making of Women's Lives. London: Pluto Press.

Womack, J. P., Roos, D. and Jones, D. (I990) The Machine that Changed the World. New York: Rawson Associates.

Wood, S. (1982) The Degradation of Work? Skill, De-Skilling and the Labour Process. London: Hutchinson.

Worthen, H. (200I) The Working Knowledge of Union Representatives in Piece Rate Apparel Shops: An Activity-Theoretical Analysis. Unpublished Manuscript, University of Illinois, Chicago, USA.

Zimbalist, A. (1979) Case Studies on the Labor Process. London: Monthly Review Press.

Zuboff, S. (1988) In the Age of the Smart Machine: The Future of Work and Power. New York: Basic Books. 